\title{
1. The bright and adventurous future of consumer law research
}

\author{
Hans-W. Micklitz, Anne-Lise Sibony and \\ Fabrizio Esposito
}

For decades, consumer law has been the stepchild of the legal discipline, neither public nor private law, not classic but postmodern, not 'legal enough', 'too political', in short, a discipline at the margins, suffering from the haut goût and striving to change society through law for the 'better'. Just like Atreyu, Frodo Baggins, Luke Skywalker, the Ghostbusters, Naruto Uzumaki, Dreamworks' dragon trainer, and many others, consumer law is the underdog carrying the burden of saving the day.

Times are changing. We are perhaps reaching the point at which the world comes to understand the real value of consumer law in a society that is dominated by and dependent on private consumption. Publishing houses and ever more numerous researchers from public and private law perspectives, working on national, European and international law are getting into what is no longer a new legal field. Now the time is ripe for a whole Handbook on Consumer Law Research which brings methodology to the fore.

This first chapter pursues three aims: first, to embed consumer law research into the overall development of legal research since the rise of consumer law in the 1960s; secondly, to explain our choice to focus on the behavioural turn in consumer law research and present the range of contributions in this volume that engage with the upcoming strand of research; and thirdly, to explore how the recent attention to behavioural insights can be combined with a pre-existing body of doctrinal research ${ }^{1}$

1 Geraint Howells, Christian Twigg-Flesner and Thomas Wilhelmsson, Rethinking European Consumer Law (Edward Elgar 2017); Dorota Leczykiewicz and Stephen Weatherill (eds), The Images of the Consumer in EU Law, Legislation, Free Movement and Competition Law (Hart Publishing 2016); Norbert Reich, Hans.-W. Micklitz, Peter Rott and Klaus Tonner, European Consumer Law (2nd edn, Intersentia 2014). 
and social legal research in consumer law, ${ }^{2}$ and outline avenues for further research.

\section{CONSUMER LAW RESEARCH, LEGAL RESEARCH AND LEGAL METHODOLOGY}

The development of the consumer or consumption society, the rise of consumer law and the emergence of consumer law research go hand in hand. The cautious move from a production to a consumption society started after the First World War. It was brutally interrupted through the Second World War, and regained pace in the after-war period all over Europe, while the US was 10 years ahead. The turning point of consumer policy - not yet consumer law - was the famous declaration of President John F. Kennedy on 13 March 1962, in which he outlined the basic rights of consumers. ${ }^{3}$ Much more obvious than the gradual transformation of the society were the scandals and crises that accompanied consumer law and policy from the beginning. ${ }^{4}$ Ralf Nader's Unsafe at Any Speed, 5 published only a year after the Kennedy Declaration, describes and analyses the construction and production deficits of the American car industry. His book not only gained cult status, but also stood as a paradigmatic monument for what was to turn into the constitutive driver of consumer law, namely, an endless chain of scandals, large and small. It suffices to recall Thalidomide, Glycol wine or Dieselgate, at the 'upper' level (protection of health and safety), or overpriced consumer credits, Schrottimmobilien ('junk property') or the subprime crisis at the 'lower' level (protection of economic interests).

2 Two strands were coming together - the law and society movement in the US and Rechtsoziologie (socio-legal studies) in Europe.

3 Drawing on the work of Helen Ewing Nelson, four basic rights were identified: (1) the right to safety, (2) the right to be informed, (3) the right to choose and (4) the right to be heard. Video footage of this speech can be found at http://www.presidency.ucsb.edu/ws/?pid=9108 (accessed 23 March 2018).

4 Peter Rott and Claudius Torp, 'Ereignishaftigkeit und Rechtsentwicklung in der Verbraucherpolitik. Eine historische und rechtswissenschaftliche Annäherung an den Umgang mit Krisen und Skandalen seit den 70er Jahren', in Christian Bala and Wolfgang Schuldzinski (eds), Beiträge zur Verbraucherforschung. Band 7: Verbraucher in Geschichte und Gegenwart. Wandel und Konfliktfelder in der Verbraucherpolitik (Verbraucherzentrale NRW 2017), 187.

5 Ralph Nader, Unsafe at Any Speed: The Designed-In Dangers of the American Automobile (Richard Grossman 1965). 


\section{US Policy, OECD and the EU}

In the first decades of the consumer movement, politically associated with the change from the Democratic President Carter to the Republican President Reagan, the US set the tone with groundbreaking changes in the development of product safety law, consumer credit law and financial services, as well as consumer class actions and the mandate granted to the Federal Trade Commission to fight unfair and misleading advertising. ${ }^{6}$ The US channelled the new policy field via the Organisation for Economic Co-operation and Development (OECD) to Europe. Within the OECD, the newborn Consumer Policy Committee initiated a series of consumer policy documents in the 1970s and 1980s, largely inspired by the US innovations. Until the adoption of the Single European Act, European institutions, more precisely the European Commission, had a weak legitimacy resulting from the two consumer policy programmes of 1976 and 1981 adopted by the European Council with a thin legal basis in the Treaty. ${ }^{7}$ In the aftermath of the Single European Act, the European Commission discovered consumer policy and consumer law as a key instrument to complete the Internal Market Project. ${ }^{8}$ This was the birth of the confident consumer rhetoric (which later culminated in the 'reasonably well-informed and reasonably observant and circumspect' average consumer standard coined by the European Court) ${ }^{9}$ and its potential

6 For a comparison between US and EU consumer law, see Geraint Howells and Thomas Wilhelmsson, 'EC and US Approaches to Consumer Protection Should the Gap Be Bridged?' (1997) 17 Yearbook of European Law 207. With regard to the role and function of the Federal Trade Commission, see Norbert Reich, Staatliche Regulierung zwischen Marktversagen und Politikversagen: Erfahrungen mit der amerikanischen Federal Trade Commission und ihre Bedeutung für die Entwicklung des Verbraucherschutzrechtes (Müller 1984).

7 The European legitimacy in the field was weak because the Treaty on the Functioning of the European Union (TFEU, also known as the Treaty of Rome), then in force, contained no reference to consumer protection among the general political aims of the European Union (EU) and, consequently, no specific legal basis to legislate on consumer protection (consumer protection was first introduced in the Maastricht Treaty of 1991). The sole legal basis available concerned the good functioning of the internal market (what is now art 114 TFEU).

8 Highly influential, the so-called Sutherland Report, see Stephen Weatherill, EU Consumer Law and Policy (2nd edn, Edward Elgar 2013), 1.

9 This standard first appeared in Case C-210/96 Gut Springerheide, EU:C:1998:369, para 31. 
abuse. ${ }^{10}$ Before that date, consumer policy was largely in the hands of the member states, which developed their particular version of consumer law within the respective legal traditions and legal cultures.

There was a type of competition between the OECD and the European Union (EU) Commission between the late 1970s and early 1980s. Backed by the new mandate in the Single European Act in 1985, the EU took over and became the main driver of consumer policy and consumer law ever since. The political debate on EU enlargement revitalised the institutional conflict between the EU and the OECD, at least for a short while. However, when the old member states decided to open the doors of the EU to the former communist states in Middle and Eastern Europe, the OECD lost its political influence. ${ }^{11}$ The enlargement allowed the EU to make accession of candidate states conditional on adjusting their legal systems. Since the 1970s, the former communist states had also experienced a move towards a consumption society - though much less developed than in the West - that left traces in their socialist legal systems. There was a particular variant of consumer law and policy in the communist states that never gained political attention in the enlargement process. The imposition of EU consumer law on the new member states led to the coexistence of the old socialist and the new democratic laws side by side, at best an amalgam of former socialist laws and legal cultures with the new consumer laws adopted before and after EU membership. ${ }^{12}$

In recent years, the OECD is back in the game of inspiring EU consumer law as it has developed an interest in behavioural insights in

10 Stephen Weatherill, 'The Evolution of European Consumer Law and Policy: From Well Informed Consumer to Confident Consumer' in Hans-W. Micklitz (ed), Rechtseinheit oder Rechtsvielfalt in Europa?, Rolle und Funktion des Verbraucherrechts in der EG und MOE-Staaten (Nomos 1996), 423; Thomas Wilhelmsson, "The Abuse of the "Confident Consumer" as a Justification for EC Consumer Law' (2004) 27 Journal of Consumer Policy 317.

11 See Hans-W. Micklitz, Rechtseinheit oder Rechtsvielfalt in Europa? - Zur Rolle und Funktion des Verbraucherrechts in den MOE-Staaten und in der EG (ed and author), Band 1 der Schriftenreihe des Instituts für Europäisches Wirtschafts- und Verbraucherrecht (VIEW) (1996).

12 The references from the new member states in the field of consumer law are telling examples of the difficulties the advocates general and judges face in understanding, in the true sense of the word, the deeper origins of the legislative 'mess'. 
general and consumer law in particular. ${ }^{13}$ Its Consumer Policy Committee in particular constitutes a forum where the Commission brings its own experience and from which it takes inspiration. ${ }^{14}$

\section{Three Waves of Consumer Law and Policy between 1962 and 2017}

Sixty years of consumer policy and law reflect first and foremost the interconnection between the US and the European states in the post-war period, with the OECD being the spider in the web, more a catalyst than a rule-maker. We might speak of those times as a period of national experimentalism, where every Western democratic state developed its own version of consumer law and policy. The consequences can easily be detected when it comes to the law in action, when the seemingly identical rules in the books have to reflect life. Enforcement is, generally, in the hands of the member states. Through enforcement, member states cannot necessarily de jure but can de facto reintegrate EU-made law into their national legal systems. ${ }^{15}$

The second and, for Europe, decisive move resulted from the institutionalisation of consumer law and policy in the hands of the EU from the mid 1980s on. European consumer law and policy developed a genuine understanding of the new policy field within the internal market-building project and perhaps beyond, as the wish, hope or fear of a genuine European society and a European identity. What matters is that EU consumer law disconnected from the political and legal development in the US and became independent. The institutional move from the OECD towards the EU resulted in a reduced internationalisation. The EU felt like the trendsetter, not only for Europe but also beyond. Throughout the 1980s and until 2000, there were relatively few interactions between the EU and the OECD, and the same is true of interactions between the EU and the United Nations (UN) - which had elaborated the UN Consumer Guidelines in 1985.

13 For general OECD resources on behavioural insights, see http://www. oecd.org/gov/regulatory-policy/behavioural-insights.htm (accessed 23 March 2018).

14 In 2017, the Committee published a report on the 'Use of Behavioural Insights in Consumer Policy', accessed 23 March 2018 at http://www.oecdilibrary.org/industry-and-services/use-of-behavioural-insights-in-consumer-policy_ c2203c35-en. A report on improving online disclosures with behavioural insights is forthcoming in 2018.

15 Hans-W. Micklitz and Andrea Wechsler, The Transformation of Enforcement in Europe (Hart Publishing 2016). 
In an extremely insightful analysis, J. Whitman explains the differences between US and EU consumer law in terms that are both novel (for the discipline of comparative law) and quite old, since he revives a dichotomy from the 1930s. ${ }^{16}$ He calls 'producerist' a legal order which tends to revolve around rights and interests on the supply side of the market: it focuses on the interest of some class of producers or distributors (such as workers, small shopkeepers, or the competitors in a given industry). By contrast, he calls 'consumerist' a legal order which tends to focus on rights and interests on the demand side of the market. This distinction captures elements which are deeply rooted in history, culture and tradition, and can help explain a variety of features in a legal system, not just consumer law. Although Whitman does not write about EU consumer law, his perspective sheds an interesting light also on this area of law. European Union consumer law, too, is characterised by a tension between consumerism and producerism. On the one hand, it emerged as a building block of the internal market, tackling a need to harmonise diverging national consumer laws in order to suppress regulatory barriers to trade. This market-building logic is inherently 'producerist' in that it focuses primarily on the relations between producers. What is more, the whole endeavour of EU law is to harmonise national laws which, in Whitman's terms, are themselves strongly 'producerist'. ${ }^{17}$ In this sense, EU consumer law has a doubly 'producerist' background. This creates an inherent tension with the American brand of consumerism, which focuses on consumers' economic interests in buying goods and services as cheaply as possible and having the greatest possible choice. Traditionally, national laws in Europe focus more on other aspects of consumers' interests: safety and quality of products, maintaining choice between different types of distribution channels (small shops/ supermarkets). This can explain why consumer law in Europe focuses more on consumer rights (product safety, legal rights such as right of

16 James Q. Whitman, 'Consumerism versus Producerism: A Study in Comparative Law' (2007-08) 117 Yale Law Journal 340.

17 See his discussion of French and German law (Whitman (n 16). In Whitman's terms, the legal systems in France and Germany appear 'producerist', notably because their legal systems put far more emphasis on workers' rights and protection of small shop versus large supermarkets rather than on cheap prices for consumers. In Whitman's terminology, workers are a type of producers, and distributors are also on the side of 'producers'. What his distinction focuses on is which conflicts a legal system gives more attention to; conflicts between workers and employers as well as conflicts between several groups of distributors are all on the producers' side. 
withdrawal and guarantees, and the right not to be influenced by abusive marketing practices) rather than on ensuring that consumers can buy products and services as cheaply as possible. In the process of harmonising such laws, EU law necessarily inherited a producerist colouration. This is in tension with the rhetoric of the past 20 years, which brings consumers' economic interests to the fore. Since the Single European Act, both the market-integration perspective and the nature of national laws to be harmonised resulted in an endeavour to provide the integrated market with a 'social face'. The EU social face should not be equated with the type of social regulation the nation states developed in the social welfare hype. ${ }^{18}$ The welfare state ideology was on the decline when the EU took over consumer law and policy. With good reasons, we might argue that the EU 'saved' consumer law and policy. ${ }^{19}$ This is obvious when we compare the rise of consumer law and policy in Europe in the 1990s with the growing indifference that consumer law and policy met in the US during the same period.

The third move took shape only gradually but it can be traced back to the fall of the Berlin Wall, the collapse of communism and the changes in the world financial order that started with the collapse of the Bretton Woods Agreement in the late 1970s. Consumer law had to go global together with the economy and with society, not to mention the boost of digital technologies. The well-protected European enclave of consumer law that was meant to preserve a transnational version of the social welfare state had to face the pressure of the global economy. ${ }^{20}$ In this regard, the turning point in the EU is not a treaty amendment but the Lisbon Summit declaration of 2000. The heads of state proclaimed the EU would become 'the most competitive economy of the world'. ${ }^{21}$ It was a political decision taken at the highest institutional level of the EU that deeply transformed the consumer law landscape through the introduction

18 Fritz Scharpf, Crisis and Choice in European Social Democracy (Cornell University Press (UP) 1991).

19 We borrow this apt expression from N. Reich.

20 Hans.-W. Micklitz and Dennis Patterson, 'From the Nation State to the Market State: The Evolution of EU Private Law'(2012) 15 EUI Working Paper also published in Bart van Vooren, Steven Blockmans and Jan Wouters (eds), The EU's Role in Global Governance: The Legal Dimension (Oxford University Press (OUP) 2013), 59.

21 Accessed 23 March 2018 at http://www.europarl.europa.eu/summits/lis1_ en.htm. 
of impact assessments, the 'better regulation'22 or nowadays the 'smart regulation' approach. ${ }^{23}$

The reaction in academia is divided, one camp claims the EU to be at the forefront of neo-liberalism, the other understands the move as an attempt to hold together social policy objectives and the competitiveness imperative through its emphasis on market efficiency. ${ }^{24}$ Lehman Brothers and the Euro crisis are standing in the limelight of the debate on the clash between economic efficiency and social policy. This is where we are now. Consumer law and consumer policy are at the centre of current debate, not least through what is called financialisation, ${ }^{25}$ the disconnection of finance from the market for goods and services and its reconnection via political action, in the EU via adjustments to the European Monetary Union and the establishment of the Banking Union. The Mohamed Aziz saga ${ }^{26}$ is paradigmatic for the dimension of the conflict. Which should prevail - the rights of Spanish home-owners not to be charged excessive interest or other costs on their mortgages - in Spain alone, $€ 5$ billion - or the rights of the Spanish banks to protect

22 'Better regulation' is defined by the Commission as 'designing EU policies and laws so that they achieve their objectives at minimum cost'. The first better regulation programme was launched in 2002. The approach was last outlined in the Commission's communication 'Better regulation for better results - an EU agenda' $\operatorname{COM}(2015) 215$ final. As part of the better regulation approach, the Commission has developed a prolific 'toolbox': accessed 11 September 2017 at https://ec.europa.eu/info/better-regulation-toolbox_en.

23 The Commission launched its Smart Regulation agenda 'to further improve the quality of EU legislation to enhance growth, jobs and competitiveness' in 2010. Smart Regulation in the European Union, COM(2010) 543 final. Smart Regulation targets the whole policy cycle, from when a policy is designed to when it is put in place and finally evaluated.

24 On this debate, see the editor's introductory chapter in Dimitry Kochenov, Gráinne De Búrca and Andrew Williams (eds), Europe's Justice Deficit (Hart 2015).

25 Joseph Vogl, Das Gespenst des Kapitals (Diaphanes Verlag 2010).

26 Hans-W. Micklitz, 'Mohamed Aziz - Sympathetic and Activist, but Did the Court Get it Wrong?' in Anna Sodersten and J.H.H. Weiler (eds), Where the Court Gets It Wrong (European Constitutional Law Network 2013), accessed 28 March 2018 at http://www.ecln.net/florence-2013.html; Hans-W. Micklitz, Irina Domurath and Guido Comparato (eds), 'The Over-Indebtedness of European Consumers - a View from Six Countries' (2014) 08 EUI Working Paper EUI-ERC; Hans-W. Micklitz and Irina Domurath (eds), Consumer Debt and Social Inclusion in Europe (Ashgate 2015). 
themselves against financial losses - that is, social rights of consumers or economic rights of the banks? ${ }^{27}$

\section{Back to Consumer Research and to Methodology}

How is the rise of consumer law and the shift from a nation state-driven policy field coordinated via the OECD under the auspices of the US to an EU centred and much more centralised policy management reflected in consumer research? What are the consequences from the emergence of a European producerist-style consumer law in contrast to a US consumerist consumer law? ${ }^{28}$ How are the EU enlargement towards the East and the South and the tension between producerism and consumerism reflected in consumer law research? Does the rise of the competitiveness imperative enshrined in the market efficiency paradigm in the EU after 2000 bring US and EU consumer research and consumer methodology closer together? Each wave - this is the hypothesis - triggered its own type of consumer research. This is what might be called the politics of consumer research and, as consumer research necessarily implies decisions on the type of methodology used, it is in effect the politics of methodology which is at stake. Consumer law, consumer legal research and consumer methodology are deeply intertwined with law, legal research and legal methodology.

Consumer law, consumer legal research and consumer methodology are paradigmatic for the ebbs and flows of what is now called the 'law and ...' discourses, ${ }^{29}$ on how law is interconnected with sociology, political sciences, psychology and economics. This is an old family of discourses that goes back to the late nineteenth and early twentieth centuries. It focused on private law, on codification, on methods of interpretation, stamped by a strong academic interchange between European (Austrian, French, German and Italian) and American scholars, who were all facing the same challenge: what kind of changes does the industrial age request from law and the legal system? The political

27 The ECJ does not provide a clear direction: in Gutiérrez Naranjo C-154/15, C-307/15 and C-308/15 it is ready to protect the house owners and to put the burden on the Spanish banks; in Cases C-8/15 P to C-10/15 Ledra Advertising Ltd, EU:C:2016:701, the ECJ rejects any liability of the Troika for the haircut of Cypriot bonds. On the Spanish banks saga, see Chapter 4 in this volume.

28 Whitman (n 16).

29 Victoria Nourse and Gregory Shaffer, 'Varieties of New Legal Realism: Can a New World Order Prompt a New Legal Theory?' (2009) 95 Cornell Law Review 61. 
economy of labour law and industrial relations stood at the centre of the debate. Consumer law in the way we understand it today arrived half a century later. The academic debate on how to integrate the new policy field into the legal system, however, bore amazing resemblance to the labour law discourse. ${ }^{30}$ As it is not the purpose of a book on consumer law research to tell the history of legal research and legal methodology, not even the history of consumer legal research, we would like to choose 1968 as the starting point.

Why 1968? This is a book written from a European perspective by European scholars from all over Europe, in the lingua franca of Europe, but without one single native English speaker among the contributors. It is neither a full-fledged US-EU comparison, although, admittedly, the US legal research plays an important role in the overall discourse, nor a bird's eye view that takes consumer research from outside these two continents into account. For post-Second World War Europe, this is the argument: 1968, the political turmoil around what the French call a revolution and the Germans a student révolte, set the tone and framed the debate on consumer law and consumer policy as a social and political project.

The post-war period is characterised by the key objective that is well documented in the Schuman declaration of 1950 - peace through cross-border trade. The European states were engaged in rebuilding society and the market. Nineteen sixty-eight left a deep imprint on the legal discourse in and around Europe, but not only in Europe. 'The Social' gained pace. ${ }^{31}$ The prevailing approach to consumer policy issues was socio-legal research financed by the respective member states to identify the problems consumers encountered and to propose solutions which could be translated into legislation. ${ }^{32}$ Looking back, we might identify the early consumer research as deeply embedded in society. Consumer policy and consumer law should help establish a 'better' and

30 Michel Miaille, Une introduction critique au droit (Maspero 1976); Enzo Roppo, 'Verbraucherschutz und Klassentheorie' (1976) Demokratie und Recht 109; Klaus Tonner, 'Verbraucherschutz und Klassentheorie - Erwiderung auf Enzo Roppo' (1976) Demokratie und Recht 241; Klaus Tonner, 'Verbraucherschutz als gewerkschaftliche Aufgabe' (1979) Zeitschrift für Verbraucherpolitik 252.

31 Duncan Kennedy, 'Three Globalizations of Law and Legal Thought: 1850-2000', 'The Rule of Law, Political Choices and Developing Common Sense' both published in David Trubek and Alvaro Santos (eds), The New Law and Economic Development (Cambridge University Press (CUP) 2006), 19.

32 See Chapter 13 in this volume. 
'more just' society to the benefit of all. Access to justice and particular consumer issues, such as consumer credit, were highlighted. The other policy fields were labour law and family law. ${ }^{33}$ This approach gradually came to a halt with the decline of the welfare state in member states and the increasingly visible difficulties in enforcing these new laws, more through agencies than courts.

The shift of consumer policy to the EU did not change the socio-legal approach. The European Commission carefully prepared regulatory action in the field of consumer law through comparative research, in the beginning limited to 'key' countries which allowed those who had to execute these studies to engage national reporters who knew their own country. The task of the responsible institution which was mandated by the Commission was mainly to prepare a comparative report. Comparative analysis aimed to legitimise the search for the best solution, which was often a mix of regulatory instruments, taken from different national legal orders. Gradually the research strategy of the European Commission changed. Two objective factors can be identified behind this change: first, the growing number of member states. In 1994 Austria, Finland and Sweden joined the EU. This triggered the need to include the variety of different legal orders in the set of selected countries. This trend continued with the EU enlargement to the East, which gained pace in the late 1990s. The European Commission put considerable resources into all sorts of activities that helped prepare the accession of the Central European states. In particular, it sponsored a kind of research that aimed to identify the degree to which the legal systems of the candidate states were complying with the existing body of EU consumer law. It was more technical than socio-legal and it did not look deeper into the feasibility of the legal transplant. This has been described and analysed elsewhere. ${ }^{34}$

The second factor was the most recent Commission-led impetus in consumer research in Europe launched in the wake of the 2000 Lisbon summit, which placed strong emphasis on competitiveness and market efficiency. In this context, cost-benefit analysis became an important feature in EU policy-making. Just like other policy initiatives, new consumer law projects now had to be tested for their impact on the

33 Armin Höland, 'Die Rechtssoziologie auf dem Weg vom Hamburger MPI zum Bremischen ZERP', in Christian Joerges, Tobias Pinkel and Ulf Uetzmann (eds), Josef Falke zum 65 Geburtstag (2014/1 ZERP Diskussionspapier), 25.

34 Rob van Gestel and Hans-W. Micklitz, 'Comparative Law and EU-Legislation: Inspiration, Evaluation or Justification?' in Maurice Adams and Dirk Heirbaut (eds), The Method and Culture of Comparative Law, Essays in Honour of Marc van Hoecke (Hart 2014), 301. 
market. The potential costs of regulatory actions had to be specified. This resulted more generally in a greater opening of policy discussion to law and economics as well as, more recently, to behavioural economics studies. Although statistics are not available, the European Commission has undoubtedly become a very important sponsor of various strands of consumer research in the EU. The challenge for such sponsored research is to combine academic rigour and creativity with the very strong orientations which underpin the studies commissioned by the EU institutions. ${ }^{35}$

In this context, it seems particularly timely to reflect on methods in consumer research. Contributors to this volume have endeavoured to do so and their reflections may be summarised as follows.

\section{THE CONTRIBUTIONS TO THIS VOLUME}

The structure of this volume is unusual for a publication on EU consumer law. The flow of the chapters does not move from any attempt to

35 A case in point is the Consumer REFIT (http://collections.internetmemory. org/haeu/20171123130248/http://ec.europa.eu/consumers/consumer_rights/review/ index_en.htm, last accessed 17 August 2018). This exercise showed how the requested research is overdetermined with requirements that can hardly be met in the allocated time frame but serve to justify regulatory action within the self-set boundaries of 'better' and 'smart' regulation. The questions asked about existing directives pertained to five dimensions: effectiveness, efficiency, relevance, coherence and EU added value. The Consumer REFIT has resulted in a proposal for a directive that would amend four directives (unfair terms directive, unfair practices directive, price indications directive and consumer rights directive): $\operatorname{COM}(2018) 185$ final, published on 11 April 2018. The most important modification concerns public and private enforcement of existing rules and sanctions for the violation of consumer law (which could reach up to 4 per cent of turnover of the infringing company). Another important change would extend the application of the consumer rights directive to digital services for which consumers do not pay money but provide personal data. The proposed changes concerning enforcement procedures and sanctions are most welcome but the whole exercise appears to be primarily an attempt at gathering support for predetermined policy options. The conclusions could largely have been predicted right from the outset and it did not take an in-depth enquiry to discover that consumer rights were under-enforced. Similarly, aligning the scope of the consumer rights directive with the scope of the proposed directive on digital content only necessitated comparing the texts. To this extent, the extensive fact-finding exercise carried out for the REFIT does not appear to have played a very strong part in determining the proposed changes. 
systematise the different components of consumer law, for example, by distinguishing general consumer law (for example, unfair terms and commercial practices, health and safety) from special or sector-specific consumer law (for example, financial services, energy, sales, telecommunication, travel and transportation). Instead, the organising idea behind this book is to propose contributions that focus on the relationships between consumer law and behavioural sciences. The aim is therefore to make the contribution of behavioural sciences accessible to a wider range of academics and practitioners interested in consumer law. While many important publications can be found, also in Europe, on the use of behavioural insights in consumer legal research, these contributions are scattered in journal articles and reports. We feel it is important to create a bridge between the rich scholarly output which has accumulated over decades (doctrinal, comparative and socio-legal) and the more recent line of behavioural studies. Behavioural studies are promising and consumer law is one area of law where they already have a concrete impact, but behavioural analysis will be less relevant if it goes its own way or views itself only as a challenge to existing scholarship. It is challenging some received wisdom - most notably about the effectiveness of disclosure requirements. This is its claim to fame and therein lies its value for legal reform. However, to deliver on the potential of behavioural insights to help make EU consumer law more effective by better incorporating what science tells us about how people make decisions, behavioural analysis needs to join forces with other valuable sources of inspiration. It must be combined, rather than juxtaposed, with doctrinal scholarship, economic analysis and socio-legal studies.

This book contributes to such a blended approach. To this end, it offers an access point to the contributions of behavioural sciences and how they are being integrated to various strands of consumer legal research. Several books do so from a law and economics perspective with a focus on US consumer law, ${ }^{36}$ or on legal research in general. ${ }^{37}$ More recently, Nudge and the Law has added a broad EU law perspective on the topic. ${ }^{38}$

\footnotetext{
36 Oren Bar-Gill, Seduction by Contract: Law, Economics, and Psychology in Consumer Markets (OUP 2012).

37 Eyal Zamir and Doron Teichman, The Oxford Handbook of Behavioral Economics and the Law (OUP 2014).

38 Alberto Alemanno and Anne-Lise Sibony, Nudge and the Law: A European Perspective (Hart 2015); Fabrizio Esposito, 'Nudge and the Law: Book Review' (2015) 28 Humana.Mente, 255-74, reprinted in (2015) 6 European Journal of Risk Regulation, 331-40; Philipp Hacker, 'Nudge 2.0: The Future of
} 
However, this volume is the first to focus on consumer law in particular from a European perspective.

The book is structured to gradually explain to the legal scholar the varieties of behavioural research. Thus, Part I focuses on core conceptual and methodological aspects: behavioural concepts and their relevance for legal discourse; how behavioural insights can inform our understanding of autonomy, a central concept of consumer law; the interaction of behavioural insights with traditional economic analysis of law, which generally builds on a strong notion of rationality; and, finally, the contribution of empirical research. The chapters of Part I equip the legally trained reader with the knowledge necessary to navigate the behavioural literature. Building on these foundations, Part II illustrates recent advances in behavioural consumer legal research on specific topics: information disclosures and default rules, the use of labels in energy policy, the protection of the retail financial consumer as well as the many connections between unfair commercial practices and behavioural sciences. These contributions offer a fresh look at their subject, but - equally importantly - they are rich with insights that can be applied to other areas of consumer law (and beyond). Part III broadens the perspective. The chapters included in this last part show unambiguously that behavioural research goes much beyond nudges and biases, behavioural economics and behavioural analysis of law. The central and common message of these chapters is thus a warning against the belief that behavioural research has exhausted its momentum and we can thus move to the next 'hot topic' (for example, personalised law, algorithmic law, blockchains and smart contracts). This conclusion is premature. So many directions have still to be explored, as the contributors show: consumer behaviour research in psychology, which has developed in parallel with general behavioural research and which lawyers have yet to consider; the complicated relationship between behavioural economics and socio-economics, with the latter's rich understanding of the 'social'; the structural differences between behavioural analysis and socio-legal research, which have nevertheless to be combined to think about the future of consumer law; the potential of integrating behavioural insights and the method of comparative law to better understand the differences and similarities between the consumer law of different legal systems; the final chapter explains that, in order to have a clear understanding of the politics behind behavioural research we must

Behavioural Analysis of Law in Europe and Beyond' (2016) 24(2) European Review of Private Law, 297-322. 
look at it from a variety of extra-legal points of view, which include at least history, political science, theoretical and moral philosophy.

\section{Part I Foundations of Behavioural Consumer Legal Research}

Fabrizio Esposito (Chapter 2) discusses some basic behavioural concepts and their importance for consumer law, with a view to making this literature accessible to neophytes. To help readers to orient themselves in this debate, Esposito focuses primarily on European research and its connections with EU law. The analysis is organised on three levels, the descriptive, the axiological and the prescriptive. At the descriptive level, the author critically reviews Hansen's concept of nudge, and proposes the following definition: a nudge is an effect of the choice architecture that alters people's behaviour by making use of one or more behavioural traits. The next step is a taxonomy of nudges. Then, Esposito proposes labelling 'law and behavioural sciences', the research field investigating the legal and policy relevance of behavioural insights, and emphasises the importance of the concept of behavioural market failure. At the axiological level, instead of focusing on the opposition between autonomist and welfarist frameworks, he suggests reflecting on the importance given to individual preferences and looking at their role in legal practice. At the prescriptive level, the author reviews the behavioural toolkit and then offers some insights on how to incorporate behavioural insights in legal discourse. In this regard, he argues that the notion of the consumer as the weaker party is particularly porous to behavioural insights, and that scientific uncertainty is not a categorical reason against their incorporation. Esposito demonstrates that there is plenty of work to be done at all levels of inquiry (descriptive, axiological and prescriptive). The chapter ends with some proposals about what is, in Esposito's view, the Archimedean problem for legal research in law and behavioural sciences, namely, offering guidance to members of the legal community on how to incorporate behavioural insights in legal discourse, in particular by identifying behaviourally porous legal concepts.

Philipp Hacker (Chapter 3) articulates an original analysis of the relationship between autonomy and nudges. The chapter starts with a critique of the 'autonomy challenge' to behaviourally informed legal intervention. The challengers hold that these interventions threaten nothing less than individual liberty, autonomy and dignity. Finding the challenge unconvincing, the author offers a normative framework to evaluate such interventions based on a non-Kantian notion of autonomy.

Hacker is unconvinced by the autonomy challenge, because the challengers build upon a notion of autonomy which is either vague or 
implausible. In this context, the author proposes working in the tradition of Frankfurt and Dworkin to build a process-based conception of autonomy. On these grounds, he proposes an analytical framework distinguishing between interventions interfering with the content of the decision and those interfering with the process of decision-making. The core autonomy-based normative concern is, according to this framework, the transparency of the intervention. The author applies the framework to a multidimensional taxonomy of interventions, based on the types and the amount of information. The analysis leads to original claims, such as the claim that default rules are more autonomy-harming than physical framing. However, the finding that an intervention reduces autonomy does not make it unjustified. Indeed, autonomy is not the only social value worthy of legal protection. Therefore, autonomy-reducing interventions can be justified when additional social values are taken into consideration. In this regard, the author takes the view that the correct normative framework is the general structure of the justification of the limitation of fundamental rights based on a proportionality assessment.

Fernando Gómez Pomar and Mireia Artigot Golobardes (Chapter 4) come from traditional law and economics, and reflect on how this approach, which initially relies on price theory and very strong rationality hypotheses, can be combined with behavioural findings which have more recently entered the academic conversation about law in general and consumer law in particular. They explain why the two approaches are not mutually exclusive. Importantly, behavioural findings do not, in their view, falsify the rational choice approach. Rather, they complement it and help refine the understanding of individual choices, including consumer choices, in various contexts.

After recalling the basic tenets of the classical law and economics approach, the authors survey some of the behavioural findings that are most relevant for the analysis of consumer behaviour (such as hindsight bias, availability heuristic, overconfidence, self-control limits or bounded will power, hyperbolic discounting, endowment effect and the status quo bias). As an illustration of the relevance of these behavioural traits for consumer protection, they discuss financial contracts. Such contracts are typically complex for consumers to understand and, therefore, the way in which relevant information is presented to them makes a large difference. Firms can rationally exploit consumer foibles and choose a presentation that best suits their interests. This is where consumer protection can and does step in. In this regard, the authors discuss two lines of cases about variable interest loans in Spain. They show how the holdings in these cases may be criticised, from both an economic and a behavioural perspective, for not giving the right incentives to banks and for not taking 
consumers' real cognitive abilities into account. This opens up the discussion of how empirical data should be incorporated into decisionmaking by legislators, but also by courts deciding on remedies to consumers' imperfect rationality.

Anne-Lise Sibony (Chapter 5) offers precisely a reflection on the roles of empirical evidence in both consumer law and consumer law scholarship. Her chapter examines the roles of empirical research in consumer law. It does so from a contemporary perspective, considering the increased recourse to empirical data both in legal scholarship and in policy-making in conjunction with the behavioural turn. Addressed primarily to legal researchers educated in a doctrinal tradition, this contribution seeks to bridge the gap between empirical work and doctrinal legal scholarship. To do so, it starts by offering a typology of legal questions which, while novel, will be meaningful to doctrinal legal scholars. On this basis, Sibony discusses how each type of legal questions relates to empirical evidence. A distinction is drawn between internal legal questions (questions about how rules relate to one another) and external legal questions (questions about law and the world). It is shown that, while external legal questions about effectiveness and efficiency of rules present a natural affinity with empirics, internal legal questions can also have an empirical component. The chapter illustrates that empirical issues lie in the midst of questions about the validity, proportionality or interpretation of rules. Sibony also highlights the particular interest of one type of external legal question, namely 'realitycheck' questions, which confront implicit behavioural claims embedded in the law with what is known of consumer behaviour (or indeed firms' behaviour). She then reviews an illustrative selection of recent empirical work, which, strikingly, all pertain to external legal questions. The use of data in legal argument is characterised as essentially rhetorical though various rhetorical uses of data are distinguished. Data-based legal discourses which express a critique of existing legal regimes provide the most striking illustrations of the rhetorical power of data. The rhetorical intensity recedes in reflection about policy inception and fine-tuning of policy interventions. Yet, all the examples show that lawyers only ever use data to make arguments. Turning to enforcement of consumer law, Sibony discusses a recent trend in the literature which advocates more data-intensive enforcement methods. She explains how such proposals, along with substantive and procedural questions raised by algorithmic powered commercial practices, provide rich perspectives for further research. 


\section{Part II Advances in Behavioural Consumer Legal Research}

Franziska Weber's Chapter 6 introduces the reader to where behavioural research on consumer issues started, namely, on the other side of the Atlantic. She reviews developments in US empirical consumer research and reflects on the challenges faced in the implementation of the findings. She illustrates various ways in which behavioural insights have been informing US policy, beyond Sunstein's appointment as head of the Office of Information and Regulatory Affairs (OIRA). The empirical research reported by the author is then divided into two macro-categories, the provision of information and default rules. As regards information, research focuses mainly on the effectiveness of simplified disclosure, complexity and saliency. As default rules are a central topic in behavioural research, the author reports several studies on them - under the significant caveat that they bear the risk of a 'wholesale opt-out' by sellers. At this point, the analysis becomes more general and focuses on the challenges for behaviourally informed consumer law and policymaking, dedicating particular attention to the empirical challenges. The final section details numerous directions for future research. The author stresses that two lines of inquiry appear to be particularly promising: research on consumer heterogeneity and the interaction of different behavioural traits, and research undertaken using the Internet.

Joasia Luzak (Chapter 7) offers an informed view on the current behavioural turn in European consumer law. In their search for increased effectiveness of policy instruments, European and national policy-makers increasingly show interest in behavioural research as a source for insights on the impact of various policy measures on consumer behaviour. However, policy-makers rarely comprehensively follow recommendations of behavioural researchers, owing to the need to account for interests other than those of consumers, or disbelief in their applicability and effectiveness. Luzak discusses to what extent policy-makers base their policies on the findings of consumer behaviour research and whether their efforts appear to contribute to increasing the effectiveness of consumer protection measures. She argues that it may be inappropriate to draw any conclusions as to the soundness of behavioural research as a basis for policy-making from the shortcomings of current measures allegedly relying on its findings, where such measures have implemented behavioural recommendations only partially, owing to either normative or factual reasons. Further, she calls for more transparency in policy-making based on behavioural insights, particularly the clarification of why policy-makers veer away from recommendations based on behavioural research. The impact that behavioural research has had in European and 
national policy-making is analysed in the area of consumer protection relating to sustainable and healthy consumption. Among the types of policy interventions considered in this chapter are information obligations (eco-labelling and health claims, but also their information design), measures increasing consumers' trust (right of withdrawal and trust marks), as well as regulatory measures (consumer education, tax policies and product bans).

Kai P. Purnhagen (Chapter 8) reflects on what he calls the regulatory validity of behavioural experiments. He starts by contrasting the very different evidential standards in law and in science, as illustrated by consumer research, on the one hand, and the case law of the European Court of Justice, on the other. The Court's approach is not welcoming of empirical evidence. This is very clear when we look at the case law on the average consumer. For the Court, normative considerations trump factual evidence on how real consumers react to various commercial practices and, for this reason, such evidence is not actually required. The European Commission, for its part, shows a greater degree of openness to empirical findings and has commissioned several studies on various aspects of consumer protection. Analysing such studies, Purnhagen warns that they may not contain evidence that is robust enough to warrant policy conclusions. He points to a risk that does not only affect the European Commission in matters of consumer protection, but more broadly policy-makers who discover behavioural insights and, in their enthusiasm, might be tempted to generalise empirical results beyond their boundary conditions. Such a tendency to over-generalisation, which could, for example, lead policy-makers to consider myopically (a tendency to focus on short-term consequences of a choice to the detriment of more distant consequences), which has been shown experimentally to bias certain decisions in certain contexts, is a universal phenomenon. The risk, explains Purnhagen, is therefore that, law-makers cherry-pick those empirical results which seem to support their agenda and discard other relevant behavioural insights. If this happens, science is used rhetorically rather than as a sound basis for decision-making and, in the worst case, this leads to policy-based evidence-making rather than to evidence-based policy-making. To avoid this risk, Purnhagen submits, behavioural studies used as evidence in the regulatory process need to pass a fitness test, which he calls a 'regulatory validity test'. This is a three-pronged test assessing in turn 'legal validity', 'scientific (internal) validity' and 'social (external) validity'. The first dimension considers legal relevance of the empirical data, asking, for example, whether the consumers, in the sample used for a study, would be considered as 'average consumers' within the meaning of the legal standard as interpreted by the courts. 
More generally, 'legal validity' is about tailoring the data to the legal construct within which the study will be used to discuss legal reform. The second dimension, 'scientific validity', focuses on checking that the scientific models and methods deployed in the policy-orientated behavioural analysis reflect the state of the art in scientific thinking about systematic responses to (potential) regulation based on behavioural insights research. The third dimension, 'social validity', is about embracing the diversity of cultural norms across the EU and ensuring that findings resonate with the values and concerns of groups affected by the policy intervention contemplated.

The test proposed by Purnhagen will no doubt contribute to the current debate on the proper methodologies for behaviourally informed policies in the field of EU consumer protection. This debate is becoming increasingly more important as the European Commission - the Directorate General (DG) Justice in particular - is becoming an ever more avid consumer of empirical studies. The debate on methods is also timely in a broader context, both beyond consumer law and beyond the EU as the OECD stresses the need for methodological guidelines on behavioural public interventions.

Jan Trzaskowski (Chapter 9) presents and discusses consumer protection aspects of marketing regulation. He reflects on the 'behavioural turn' in this area and explores how behavioural sciences may be used to reconstruct this legal field. He starts from the core piece of EU law on commercial practices, the directive on unfair commercial practices, and identifies two central legal notions which can meaningfully be discussed in light of behavioural insights, namely, the 'average consumer' and 'professional diligence'. He then discusses these two normative abstractions both in light of empirical evidence from behavioural sciences and taking into account current developments in marketing techniques. In the remainder of the chapter, Trzaskowski turns to two difficult questions, both of which concern the role of science-based arguments in normative decisions. The first question is central to the regulation of unfair commercial practices: can behavioural sciences help draw the line between permissible influence (marketing is all about influencing consumers and this is considered legitimate) and prohibited distortion of consumers' economic behaviour? The second question broadens the focus and is of relevance for the whole of consumer law: how do we define the desirable level of consumer protection, taking into account that it involves a delicate balancing exercise between paternalism and the consumer's right to self-determination.

Geneviève Helleringer (Chapter 10) deals with consumer protection in financial markets. These markets offer a particularly fertile ground for 
reflection on behaviourally informed regulation, because the supply of financial products is characterised by a high level of complexity, and demand from retail investors is strongly shaped by behavioural traits, cognitive limitations and poor financial literacy. Studies suggest that stakes are high: as much as one-third of borrowing charges consumers pay might be attributable to their ignorance of the implications of their actions. Regulatory responses, therefore, are warranted. As Helleringer explains, existing regulations have been designed to protect financial consumers and make them better off, but well-meaning interventions may sometimes backfire and make consumers worse off when they contain behavioural blind spots or are miscalibrated. Looking at this body of regulation through a behavioural lens shows that calibrating such regulation with the required degree of precision is a delicate task. The two most important elements regulators have to take into account are the limited cognitive power of financial consumers and their preference for the present. In the words of Helleringer, these are two mounts at the tip of the behavioural iceberg on which traditional regulatory interventions have often crashed. Such failures, she explains, happen even as behavioural realities are occurring in the regulatory conversation. This is because financial firms are often in a position to exploit behavioural traits, which only increases the need for regulators to take into consideration behavioural realities. It also strengthens the case for performancebased requirements that put the onus on firms to harness behavioural traits in a manner that is favourable to consumers (rather than merely trying to counteract private strategies that leverage the same behavioural traits in the interest of financial intermediaries). Meanwhile, interventions designed to modify the choice architecture can be truly effective under certain conditions. In particular, there is a growing interest in personalised regulatory interventions that take into account individual differences in behaviour and degrees of rationality and financial literacy. As is clear from this contribution, financial markets offer a view of a rather advanced, if behaviourally imperfect, brand of consumer protection. This contribution will not only be of interest to specialists of consumer finance, but, more broadly, to researchers engaging with the challenges of consumer protection in other complex areas where consumers understand equally little about the terms of transactions they engaged in, such as online dealings where consumers pay for services (in part or in totality) with data. 


\section{Part III Insights from Broader Perspectives}

Michiru Nagatsu and Magdalena Małecka (Chapter 11) outline a history of various strands of behavioural research pertaining to consumer behaviour. Broadly defined, consumer research is scattered across disciplines such as economics, psychology, sociology and anthropology, to name a few key disciplines, as well as marketing and business research conducted primarily in business schools. However, there is another, more pertinent, reason why they do not focus on consumer behaviour. Behavioural economics and 'law and the behavioural sciences' have roots in the developments of a much more general study of human (and animal) behaviour. If we want to understand these roots, the historical focus should be on behavioural research in general rather than on consumer behaviour research. Therefore the authors first look at the current field of consumer behaviour research qua a sub-discipline of marketing. This discussion reveals the multidisciplinary nature of the field, which takes us next to the history of general trends in psychology that exert influences on many disciplines, and then to more specific developments in behavioural research at the intersection of economics and psychology. In the final section, the authors review how these strands of behavioural research have been taken up by legal scholars at various points in history. Their conclusion is that the legal scholars were mostly influenced directly by contemporary basic behavioural research, instead of indirectly by consumer behaviour research. Whether and how the latter will be taken up by legal scholars in a more systematic way remains to be seen.

Sabine Frerichs (Chapter 12) takes the pointed criticism from social sciences against behavioural economics as a starter. The focus of the claim is that behavioural economics has an impoverished understanding of the 'social'. In order to drive the argument home, the chapter follows a twofold aim. On the one hand, it seeks to reconstruct the methodological foundations for a policy of nudging, which has become a central reference point in discussing the normative implications of the behavioural turn. On the other hand, the chapter aims to work towards a broader assessment of the methodological position of behavioural economics against the backdrop of old and new methodological debates within and beyond the economic discipline. This requires opening up the perspective beyond the 'cognitive' component of behavioural economics to give more space to what has been referred to as its 'social' component. This is still a selective take on scholarship in this field, but it helps to refine the criticism from the viewpoint of its contenders. To compare and interrelate behavioural economics and socio-economics is a third goal of this chapter. Lacking this critical potential, the author concludes, the 
'choice architectures' of libertarian paternalism ultimately tell us more about '[behavioural] economists' conceptions of economics and of the social world' than about the world as it really is, in all its social contingencies.

Florian Möslein (Chapter 13) puts the relationship between new behavioural economics and socio-legal research into focus. Behavioural analysis has not only gained remarkable attraction with policy-makers, but it has also largely replaced socio-legal research which used to accompany the making of European consumer law during the first 25 years or so of its existence. The introduction of the 'better regulation' initiative and impact assessments at the turn of the millennium are partly seen as the breaking point between those two approaches, given that they shifted the emphasis on potential effects of policy changes on consumer behaviour. After explaining the fundamental importance of models of human behaviour for consumer law, the author argues that these two approaches start from fundamentally opposite assumptions: while behavioural analysis is based on the functional rationality of Homo oeconomicus with its focus on individual choice, socio-legal research roots in the value rationality of Homo sociologicus which instead draws attention to social embeddedness. Owing to the fundamental importance of those two behavioural models, the answer shapes the essential pillars of European consumer law's architecture, not only some of its ancillary decorative elements. Any future construction of consumer law, be it by legislators, courts or academia, does not require that one of the two behavioural models be selected and the other rejected, but needs both to be combined.

Giesela Rühl (Chapter 14) engages in the interrelationship between comparative law and behavioural economics. In the light of comparative law's central role in a globalised world and for the European law-making process, she examines whether and how comparative legal research in consumer law, but also beyond, may benefit from the insights of behavioural research. The chapter is organised in two parts. The first analyses the potential of behavioural analysis from the perspective of comparative law and analyses recent attempts to improve the comparative method with the help of behavioural insights. The second looks at the potential of behavioural analysis for comparative law from the perspective of economic analysis and sheds light on recent proposals to modernise the field that has become known as comparative law and economics. The chapter, in contrast, does not describe the relationship between behavioural analysis and comparative law on a meta-level. The overall message is that European legislature should not hesitate and should combine comparative and behavioural analyses more often and in 
a more systematic fashion when legislating (or when considering legislating) in the field of (substantive or procedural) consumer law. To make this possible, behavioural scientists and lawyers should work together to create the necessary cross-cultural knowledge about actual consumer behaviour.

Hans-W. Micklitz (Chapter 15) searches for the politics of behavioural economics of law. This implies a need to place behavioural legal and economic research into context - historically, politically, philosophically, theoretically and methodologically. It allows us to set a countermark to the academic, intellectual and political hype around behavioural economics. The deeper reasons are the changing societal patterns in the waves of globalisation that promoted the shift in emphasis from social to economic policies, from social sciences research guided by justice towards economic research guided by economic efficiency. The political hype results from the promise that behavioural law and economics would help design policies that are choice-preserving and able to achieve the desired results at low cost. The overall argument is that it is economic efficiency that stands predominantly behind behavioural law and economics, insinuates a value change away from the social and from the role of law, affects the autonomy of the individual and disconnects him or her from society. Behavioural law and economics is more than a research tool; it is a normative theory if not a social theory. Therefore, the politics of behavioural law and economics can and should be read as a first attempt to formulate a critical theory on the behavioural analysis of law that reduces law to economic efficiency and cognitive psychology, forgetting about the sociology of law. The chapter demonstrates how work conducted for the World Bank ${ }^{39}$ and law and economics are challenging social regulation through their universalist outlook which clashes with the deeper cultural foundations and legal traditions. What is at stake is the role and function of the individual and his or her autonomy in society. The conclusion is that only an opening up towards society and the sociology of law can demonstrate the added value of behavioural law and economics.

In sum: there are many lessons, insights and suggestions that we hope the reader will extract from the rich contributions to this volume, but there is one in particular that we found particularly consequential in an age of value and methodological pluralism such as we live in. This lesson

39 We are referring to the numerous publications by Rafael La Porta, Florencio Lopez-de-Silanes and Andrei Shleifer. 
is about group behaviour of researchers. It surfaces in the way behavioural analysts have approached scholars from other disciplines, but it is rarely made explicit. This is why we devote the final section of this introduction to this issue

\section{A BEHAVIOURAL LESSON ABOUT STREAMS AND TRENDS IN CONSUMER RESEARCH}

A few years ago, one of us published a critical reflection on the state of legal scholarship in Europe and proposed an agenda for a European debate..$^{40}$ A particularly pressing point was found in the 'risk of herd behaviour in legal research':41

herd behaviour implies that researchers choose to follow 'hot topics' and trends, often initiated by policymakers (eg the European Commission) instead of developing their own agenda. What is worse is that they do it without questioning the preconceptions on which these choices rest. ... In many cases, the authors do not even bother to explain on whose shoulders they stand.

The starting point of that reflection was the opposition between 'doctrinalist' and 'multidisciplinarian' approaches to legal scholarship and how the mainstream is dominating the research agenda. One of the proposals advanced on that occasion is of particular relevance for consumer law research, ${ }^{42}$ where the growing interest for the findings of behavioural sciences is a win for the multidisciplinarians, but takes place against a backdrop dominated by the doctrinalist approach and a lack of awareness of the long history of socio-legal research. Herd behaviour can be dangerous, but at the same time it is not necessarily bad, as long as the preconceptions and the intellectual context are disclosed. ${ }^{43}$

It takes a critical mass to make up a strand of scholarship. At the same time, the risk is that energies will be wasted in addressing problems that have already been studied for some time by others. Worse still, ignoring the relevant research produced in other research domains can lead to

40 Rob van Gestel and Hans-W. Micklitz, 'Why Methods Matter in European Legal Scholarship' (2014) 20 European Law Journal 292. This reflection has recently led to the publication of a collective volume: Rob van Gestel, Hans-W. Micklitz and Edward L. Rubin, Rethinking Legal Scholarship: A Transatlantic Dialogue (CUP 2017).

41 Gestel and Micklitz (n 40), 305.

42 Gestel and Micklitz (n 40), 313.

43 Gestel and Micklitz (n 40), 308. 
erroneous conclusions. The dilemma is when to accept and when to challenge the wisdom of the mainstream. In this regard, there is an important lesson to be learned from the behavioural movement. How the early work in psychology made its way to its successive applications in economics, in the social sciences and, finally, in its relationship with the law is a tale of integration between more and less established strands of research. ${ }^{44}$ The lesson it teaches relates just as much to the circulation of ideas in academia as it does to the substance of behavioural research. That is, as herds have leaders, it is important to understand what makes them leaders and to challenge them on their own grounds. In this way, highly original and critical research can be perceived as a constructive contribution to mainstream research. However, these leaders and their advocacy have to be placed in context and constantly questioned. This is the only way to keep the necessary distance from the field.

It is concerning when scholars respond acritically to the stimuli coming from leaders, regardless of who these leaders are (for example, the European Commission, American legal scholars and Israeli cognitive psychologists). What is at least as concerning is scholars not responding to the stimuli coming from outside the mainstream (the truck approaching at high speed or the wolves hiding in the bushes are stimuli the herd members have to be aware of). As for any other social practice, a field of research is characterised by a specialised vocabulary and a shared understanding of why some research is part of the field and other is not. At some point, even the researcher most open to interdisciplinarity will consider some findings irrelevant for his or her own field. For example, while we can understand the importance of gravitational waves for research in physics, we candidly admit that it is hard for us to see how proof of their existence can possibly matter for consumer research. However, we cannot and do not want to exclude the possibility that someone will show us how gravitational waves are important for consumer research - perhaps with regard to consumer safety.

New trends establish the conditions of admittance, but should not exclude strangers once these conditions are fulfilled, nor should they forget about previous research related to the very same subject though under a different branch of science. The establishment of behavioural economics and law and behavioural economics illustrate these points.

44 For a lively account of how Kahneman and Tversky dealt (differently, each according to his own personality) with this challenge as they were engaged in their path-breaking joint research, see Michael Lewis, The Undoing Project: A Friendship that Changed our Minds (Norton 2016). 
The ability of behavioural scientists to influence the economic debate is particularly remarkable given how closed to other disciplines economics had become (which led some to refer to economic imperialism ${ }^{45}$ ). It took Kahneman and Tversky a lot of hard work over and above their initial findings about human decision-making to make the implications of their research so clear that economists could not ignore them. It took even longer for a Nobel prize in economics to be awarded to Kahneman for their joint work (by the time Tversky had died). In the long run, the endeavour was successful, as evidenced by the Nobel prize for economics awarded to Richard Thaler in 2017. How behavioural analysts were able to successfully influence economists thus becomes a source of inspiration for those trying to steer an academic debate in new directions. However, what is missing right from the beginning is the intellectual link to the founding fathers of social behaviour and socio-legal research, to E. Ehrlich, M. Weber and later M. Galanter, D. Trubek, V. Gessner, to name just a few leading figures. ${ }^{46}$ They revitalised socio-legal research from the 1960s onward.

\section{INSIGHTS FROM THE ARGUMENTATIVE STRATEGY OF THE PIONEERS OF BEHAVIOURAL STUDIES}

In their famous Econometrica article 'Prospect theory', Kahneman and Tversky recognise the importance of expected utility theory for economists, then 'describe several classes of choice problems in which preferences systematically violate the axioms of expected utility theory' and finally 'propose an alternative account of choice under risk'. ${ }^{47}$ The same critically constructive attitude animates the 'Anomalies' column that Thaler has published with various co-authors in the Journal of Economic Perspectives. Each entry followed a preface explaining the

45 See, in particular, Magdalena Malecka and Robert Lepenies, 'Behavioural Sciences in Law and Policy: A Case of Scientific Imperialism?', accessed 29 August 2017 at https://papers.ssrn.com/sol3/papers.cfm?abstract_id=2631760.

46 Institutionally they were located at the University of Wisconsin, at the Max-Planck Institut in Hamburg until 1982, later at the Centre for European Legal Policy at the University of Bremen and at the Onati International Institute for the Sociology of Law (Spain).

47 Daniel Kahneman and Amos Tversky, 'Prospect Theory: An Analysis of Decision under Risk' (1979) 47 Econometrica 263. 
importance of rational choice theory for economics and indicating that some empirical results are 'anomalous' because they are hard to explain on its grounds. ${ }^{48}$ The entry would then typically advance a behavioural explanation of the anomaly. Notably, economists who are critical of behavioural economics also recognise that 'the heuristics and biases dissent is part of orthodox dissent' ${ }^{49}$ In this context, 'orthodox dissent' refers to economists who are not aligned with the mainstream, but whose research does not break radically with it. ${ }^{50}$ The ability of behavioural economists to be perceived as compatible with mainstream economics is thus important in understanding their success.

The lesson is, if you want to change the dominant view, stress its importance, acknowledge its validity within a certain scope (there are probably problems it can solve), focus on the areas where it struggles, explain clearly why it struggles and advance an alternative approach that can improve the dominant view. This narrative also permeates the law and behavioural economics literature. In their seminal 'A behavioral approach to law and economics', Jolls et al. open their analysis by pointing out that '[o]bjections to the rational actor model in law and economics are almost as old as the field itself', but they 'have been much less common[ly]' made by 'those who sympathize with the basic objectives of economic analysis'. ${ }^{51}$ They continue observing that in "other fields of economics ... "behavioural" analysis has become relatively common', so that its absence in the 'economic analysis of legal rules ... is especially odd since law is a domain where behavioural analysis would appear to be particularly promising'. ${ }^{52}$ The behavioural approach brings 'a better understanding of human behaviour' leading to 'more adequate prescriptions about the law' ${ }^{53}$ They conclude the introduction by stressing that the behavioural approach to law is a 'deeply constructive' project. $^{54}$ 'Law and Behavioral Science: Removing the

48 See, for example, Richard H. Thaler, 'Anomalies. The Winner's Curse' (1998) 2 Journal of Economic Perspectives 191.

49 Marc Lavoie, Post-Keynesian Economics: New Foundations (paperback edn reprinted with amendments, Edward Elgar 2015) 86.

50 Lavoie (n 49), in particular 5, 10.

51 Christine Jolls, Cass R. Sunstein and Richard Thaler, 'A Behavioral Approach to Law and Economics' (1998) 50 Stanford Law Review 1471, 1473.

52 Jolls et al. (n 51), 1473.

53 Jolls et al. (n 51), 1473, 1474.

54 Jolls et al. (n 51), 1475. 
Rationality Assumption from Law and Economics' by Korobkin and Ulen reveals a similar pattern. The article opens with the claim that the law and economics movement is not as groundbreaking as it once was, and that it has lost sight of its goal because ' $[\mathrm{m}]$ athematical elegance often becomes the primary goal, with usefulness in the realm of law ... a mere afterthought'.55 In this context, the contribution of 'borrowing from psychological and sociocultural theories in addition to economics' rests in 'understand[ing] the incentive effects of law better than modern law and economics is able to do'.56 A decade later, Cooter declared 'law and behavioural economics ... a successful insurrection that ended by granting the insurgents a prominent seat in the government' ${ }^{57}$

The stories of behavioural economics and law and behavioural economics have thus two significant points in common. First, behavioural analysts identify what is wrong with the dominant view, what the herd leaders are doing (accepting rational choice theory). Second, they claim that the dominant view has to evolve in the light of the very same commitments that justify the current leadership, studying choice in a context of scarcity and making legal scholarship more helpful for legal reform. It is worth noting that this is the very same approach that nourished socio-legal research in the 1970s and 1980s in Europe.

How does this lesson about crafting a successful rhetorical approach to consumer research relate to other strands of consumer research, such as doctrinal, comparative and socio-legal, just to name a few, all of which are also present in the current book? First, it helps clarify the positioning of the book. Behavioural analysts have grown to set a new trend, besides doctrinal, comparative and socio-legal research. Established insights from sociology and anthropology as well as insights from branches of psychology other than decision theory have not made it on to the radar of those who study scientifically informed policy-making, consumer policy included. At the time of writing, there is a communication gap on both sides. The situation seems to be that, as a matter of principle, the doors are open theoretically, but, in practice, stand by and large closed. Each

55 Russell B. Korobkin and Thomas S. Ulen, 'Law and Behavioral Science: Removing the Rationality Assumption from Law and Economics' (2000) California Law Review 1051, 1054.

56 Korobkin and Ulen (n 55).

57 Robert Cooter, 'Maturing into Normal Science: The Effect of Empirical Legal Studies on Law and Economics' (2011) University of Illinois Law Review 1475 . 
branch of research is following its own path, although there is room for mutual learning. Seen through the lenses of behavioural science, the successful rhetoric that will bring insights from sociology and anthropology and more varied insights from psychology has not yet emerged in a significant and forceful way. However, the same is true from the perspective of socio-legal research. Behavioural science is not exhausting the potential which lies in the experience gained over nearly a century on social behaviour, more particularly with regard to consumer law and consumer behaviour.

Korobkin and Ulen consider sociocultural theories as a driver of law and behavioural sciences. We see the same commitment in Akerlof et al.'s first editorial of Behavioural Public Policy, when they state that the scope of the journal is not limited to economics and psychology, but rather welcomes 'knowledge from, for example, animal behaviouralism, anthropology, evolutionary biology, law, philosophy, political science and sociology ... and given the nature of the journal, multidisciplinary work is particularly encouraged' as long as this new knowledge is useful for policy-makers. ${ }^{58}$ Alternatively, there is the long tradition of what is today called economic sociology, which goes back to Eugen Ehrlich and Max Weber. This is no more and no less than an attempt to look from a sociological perspective into the functioning of capitalism more broadly and markets more specifically. In such an understanding, economy and society belong together. Consumer law crosses the line where it reaches beyond the market and affects society.

Second, the importance of constructive criticism is as true in the field of consumer research as in any other. In any academic debate, the state of the art can be criticised in many ways. Behavioural analysts gained prominence in economics and in law and economics, up to the point that it is advisable to break free from economics and speak more generally of (law and) behavioural sciences, also because of their constructive way of engaging with the mainstream. The mainstream felt only partially threatened, to the effect that some of its members (for example, Cooter, Ulen and Sunstein) became leaders of the insurgence. Academics, especially the young, who may find it more difficult to restrain themselves when they feel strongly about something - including the current state of behavioural scholarship in consumer research - can at least find in the

58 George Akerlof, Adam Oliver and Cass Sunstein, 'Editorial' (2017) 1 Behavioural Public Policy 2. 
evolution of behavioural research a beautiful example of how constructive criticism can enhance someone's ability to enter and to contribute to the debate. In this regard, a word of caution is needed. Constructive criticism is well perceived and urgently needed when it comes to consumer law scholarship, but it should not lead to turning a blind eye to behavioural research, which is undertaken in other branches of scientific research relevant to law and to legal policy, such as political philosophy or sociology. Each discipline has its own history and its own leaders. Opening the intellectual discourse not just to one specific strand of scholarship, such as behavioural economics, but more broadly, is the ideal type of research that could be undertaken.

\section{A MESSAGE TO THE READER}

In the light of the above, we would like to underscore the spirit in which the contributions which form this volume were gathered. All of them focus on the behavioural turn in consumer law not because we think behavioural scholarship is the bright and adventurous future of consumer law research. Rather, the real adventure is in connecting behavioural insights which at present constitute the big novelty and new hype in the field with more established strands of scholarship, be they doctrinal, comparative or inspired by an already multidisciplinary perspective such as socio-legal studies or economic analysis of law. At present, behavioural insights are typically used to highlight aspects that, until very recently, were not properly taken into account in existing law or in previous strands of scholarship (such as how people react to information) and now only start to make their way into both legal reform and legal scholarship. This is only the start of the conversation. There are several directions in which we hope the readers of this book will take it further. Besides socio-legal studies, which, as previously mentioned, deserve greater attention and greater integration with behavioural insights, we would like to highlight two further directions: policy-relevant behavioural research and behaviourally informed legal research. 


\section{A Post-Nudge Research Programme in Behavioural Science}

Nudge by Thaler and Sunstein ${ }^{59}$ was instrumental in bringing the basics of behavioural sciences to a wider audience, including lawyers. In this ambassadorial role, it does a great job and can certainly serve as background reading to introduce law students to behavioural topics. However, it has also focused the attention of policy-makers and legal scholars on a small subset of behavioural insights, namely a limited number of heuristics and biases. Future research should increase depth and breadth. ${ }^{60}$

Exploring the full depth of issues raised by even a small subset of behavioural insights for consumer law is in itself a rich programme which is far from completed. Awareness of behavioural insights and good behavioural intent on the part of policy-makers may not be enough. For example, it is not enough for the law to take on board the general idea that consumers have a limited ability to process complex information about the future, especially when it is numerical in nature, and mandate simplified disclosures (for example, key investor documents, KIDs, for financial products). Once behavioural insights have been connected with existing legal tools (such as mandatory disclosures), their use needs to be fine-tuned on the basis of empirical studies (for example, by testing several different options for simplifying disclosures, as was done in the case of KIDs). Yet, ex post evaluation shows that, despite all good intent and empirical efforts, KIDs do not seem to make consumers much better off. ${ }^{61}$ Where did things go wrong?

Questions raised by such behavioural mishaps include: are there any (behavioural or other) effects that have been disregarded? (This is where breadth of analysis comes in.) Do the options tested explore the full range of relevant variations of the core idea that is being operationalised (for example, simplification compensates limited numeracy)? Were the tests conducted according to the best suited methodology on a significant sample? All of these questions are relevant for meaningful incorporation of behavioural insights in legal reform, and none of them can be

\footnotetext{
59 Richard H. Thaler and Cass R. Sunstein, Nudge: Improving Decisions about Health, Wealth, and Happiness (Yale UP 2008).

60 On this theme, in a more comprehensive sense (the author looks beyond consumer law), see Avishalom Tor, 'The Next Generation of Behavioural Law and Economics' in Klaus Mathis (ed), European Perspectives on Behavioural Law and Economics (Springer 2015), 17.

61 See Chapter 10 in this volume.
} 
answered on the basis of law alone. Some of the questions pertain to applied research, some are fundamental in nature.

In practice, at least in Europe, applied research on how to implement identified behavioural insight in a given policy-relevant context is typically conducted by nudge units, where they exist, or consultancies hired by a public authority such as the European Commission. This type of institutional setting brings certain constraints and possibly certain biases in the way policy-relevant applied research is conducted, which is in itself an area of investigation for socio-legal studies.

The questions regarding the focus of policy reforms such as 'Are the identified behavioural insights tested all that matters to make consumer policy more effective?' are truly fundamental and call for broad enquiries into the causes of consumers' conduct over and beyond their cognitive limitations and behavioural traits. At this stage, studies on contextual factors that influence consumer behaviour are not taken into account in legal scholarship. Yet, investigations on interpersonal interaction (between businesses and consumers as well as among consumers) and on group interaction appear to be a necessary complement to those studies that focus on choice architecture. ${ }^{62}$

\section{The Added Value of Behaviourally Informed Legal Research}

The aforesaid may leave the legal researcher with the impression that behavioural research is all about learning from disciplines other than law and wonder at which point the research stops being part of legal research at all. More worryingly, he or she may wonder what he or she has to contribute to a discussion on policy use of behavioural insights, when he or she is neither a producer of empirical data about behaviour nor in charge or designing procedures to incorporate scientific findings in the law. We are convinced that lawyers do have something very valuable to bring to the behavioural conversation. Only they are in a position to connect in a meaningful way arguments derived from behavioural studies or about behavioural studies to the law. Arguments derived from behavioural studies will usually take the form of statements about facts, such as 'in a field experiment, less than one in a thousand buyers were found to

62 For interesting sociological perspectives, relevant to behaviourally informed consumer policy, in particular regarding food labelling, Henri Bergeron, Patrick Castel and Sophie Dubuisson-Quellier, 'Gouverner par les labels. Une comparaison des politiques de l'obésité et de la consommation durable' (2014) 3 Gouvernement \& Action Publique 9. 
inform themselves about terms and conditions' ${ }^{63}$ Lawyers' role is to reflect on the implications of such an empirical finding. There are several distinct implications. In the given example, the implication explored by the authors of the study - and the motivation behind their study - was to counter the 'informed minority' argument. This classic economic analysis of law argument suggests that it does not matter that most people do not read the information contained in terms and conditions. It is enough, the argument runs, that an active minority does read them in order to discipline firms, because firms do not want their reputation tarnished. In this way, the active minority protects the passive majority. Here, the empirical study was constructed to deconstruct an argument in a scholarly debate about mandated disclosure as a policy tool of choice. ${ }^{64}$

The example tells us that one way for lawyers to engage with empirical findings about consumers' behaviour is to identify in their area of interest an explicit argument or an implicit premise regarding consumer behaviour that they feel sceptical about, then go out and look for relevant evidence - or produce it, possibly in collaboration with colleagues with adequate training in data collection and treatment. In this kind of work, the research question is framed to challenge received wisdom, whether that wisdom comes from a dominant school of thought (such as economic analysis of law in the above US example) or from the law itself. A (European) case in point still is the average consumer. This construct was developed by the European Court of Justice (ECJ) in an internal market perspective, mainly with regard to primary EU law and to advertising and sales promotion. What came out was a heroic figure that the Court calls 'reasonably well-informed and reasonably observant and circumspect' ${ }^{65}$ This impressive shopper not only reads contracts, he or she also goes online to check what is behind the small print in an advertisement, reads food labels and is fooled neither by colours or by the size of publicity markings relating to an increase in a product's quantity. ${ }^{66}$ It is worth

63 Yannis Bakos, Florencia Marotta-Wurgler and David R. Trossen, 'Does Anyone Read the Fine Print? Consumer Attention to Standard Form Contracts' (2014) 43 Journal of Legal Studies 1.

${ }^{64}$ It did not, however, put an end to the debate: see 'Book Symposium on Florencia Marotta-Wurgler's Studies' (2015) 12 Jerusalem Review of Legal Studies.

65 Established case law since the judgment of 16 July 1998, C-210/96 Gut Springerheide, EU:C:1998:369, para 31.

66 For references to the case law on all these points, see Geneviève Helleringer and Anne-Lise Sibony, 'European Consumer Protection through the Behavioral Lens' (2016) 23 Columbia Journal of European Law 607. 
confronting these jurisprudential 'images of consumer' with extant empirical findings. ${ }^{67}$ It is also worth running new empirical studies to confront the representations that emerge from the case law. ${ }^{68}$ Once a discrepancy is established, the next step is to return to the discussion about law and tease out the consequences to be drawn.

This is where lawyers have a comparative advantage. Anyone can see that, if consumers do not read terms and conditions, it is silly to expect that information conveyed to them in this habitual written form will not serve to inform their decisions. However, it takes an in-depth knowledge of the whole system of consumer protection to discuss meaningfully the implications and have a sense of whether it would be sensible, for example, to do away with information requirements altogether and, if so, what alternative techniques are available, and, if not, what improvements can reasonably be contemplated in line with the existing legal framework, for example, mandating simplified disclosures, just in time information, different media or reminders.

Beyond specific policy recommendations, and in the best-case scenario before making policy recommendations, law researchers are uniquely placed to reflect on broader questions, such as what does the flurry of behavioural criticisms against mandatory disclosure do to the information paradigm, which is a building block of European consumer law? The debate about behaviourally informed intervention brings us back to fundamental questions such as: what exactly do we want to protect consumers against? What is the autonomy our legal system wants to preserve? ${ }^{69}$ In what kind of society to we want to live in? Behavioural insights open up questions about notions lawyers tended to take for granted, thus also creating a research opportunity from a doctrinal perspective (and not just from an empirical perspective).

Another type of research questions lawyers are uniquely positioned to tackle pertains to interpretation of vague legal notions. Confrontation, mentioned above apropos the average consumer, is not the only mode of interaction between the law as it stands and empirical findings about

67 We borrow the apt expression from Dorota Leczykiewicz and Stephen Weatherill, The Images of the Consumer in EU Law Legislation, Free Movement and Competition Law (OUP 2016).

68 Kai P. Purnhagen and Erica van Herpen, 'Can Bonus Packs Mislead Consumers? A Demonstration of How Behavioural Consumer Research Can Inform Unfair Commercial Practices Law on the Example of the ECJ's Mars Judgement' (2017) 40(2) Journal of Consumer Policy 217.

69 See Chapter 3 in this volume. 
consumer behaviour. Incorporation is another. The law is full of opentextured notions that call for interpretation: influence, fairness and vulnerability are but a few examples. It is lawyers' role to ask whether and how behavioural findings can inform the interpretation of such notions, for example, by borrowing distinctions or typologies to distinguish between different kinds of influence, different categories of vulnerable consumers or different drivers of consumer weakness and asking whether these can be used to fine-tune interpretation of a legal category.70 This type of work does not require the conducting of original empirical work. It is a conceptual exploration of how legal notions overlap, subsume or otherwise interconnect with categories that emerged from behavioural studies.

In summary, these are but a few directions in which exciting new research prospects await adventurous consumer lawyers. The following chapters illustrate them, deepen the reflection and add much substance to these remarks. We hope they provide the reader with inspiration and look forward to revising our provisional guidance in light of new and innovative research.

70 For an attempt concerning the notion of influence, see Anne-Lise Sibony, 'Can EU Consumer Law Benefit from Behavioral Insights? An Analysis of the Unfair Practices Directive' (2014) 6 European Review of Private Law 901. For an elaboration, see, in particular, Chapters 2 and 9 in this volume. 